\title{
Can the Biomonitor Tillandsia usneoides Be Used to Estimate Occupational and Environmental Mercury Levels in the Air?
}

\author{
M. F. Fonseca ${ }^{1,2^{*}}$ W. R. Bastos, ${ }^{3}$ F. N. Pinto, ${ }^{1}$ M. de F. Rebelo, ${ }^{1}$ J. P. M. Torres,${ }^{1}$ \\ J. R. D. Guimarães, ${ }^{1}$ W. C. Pfeiffere, ${ }^{1}$ R. G. Marques ${ }^{1,3} \&$ O. Malm $^{1}$ \\ ${ }^{1}$ Laboratório de Radioisótopos Eduardo Penna Franca, IBCCF, CCS, Universidade Federal do Rio de Janeiro, Rio de Janeiro, RJ \\ ${ }^{2}$ Hospital Central da PMERJ, Secretaria de Segurança Pública do Estado do Rio de Janeiro, Rio de Janeiro, RJ \\ ${ }^{3}$ Laboratório de Biogeoquímica Ambiental, Núcleo de Ciência e Tecnologia, Universidade Federal de Rondônia, Porto Velho, RO
}

(Received November 9, 2006; Accepted April 30, 2007)

\begin{abstract}
Spanish moss, the epiphyte bromeliad Tillandsia usneoides (in Brazil, "Barba-de-velho"), has been used as biomonitor to evaluate air pollutants. In this article, total $\mathrm{Hg}$ concentrations were determined in bromeliads exposed at different areas of a Brazilian chlor-alkali plant while a calibration curve was built under controlled conditions in order to estimate atmospheric $\mathrm{Hg}$ concentrations. Hg determinations were performed by atomic absorption spectrometry. In the laboratory, the bromeliad exhibited linear $\mathrm{Hg}$ retention $(\mathrm{r}=0.99 ; \mathrm{p}<0.05)$ when exposed to different $\mathrm{Hg}$ concentrations for 15 days under controlled conditions. While Tillandsia usneoides allows simultaneous and continuous monitoring of several workplaces inside a factory, identifying critical areas where workers can be overexposed, we conclude that bromeliad biomonitoring does not appear to be a trustworthy procedure to estimate $\mathrm{Hg}$ concentration in the air. However, this just can be a useful method for identifying and monitoring critical sites in continuous occupational and environmental control risk programs.
\end{abstract}

Key words: mercury, Tillandsia usneoides, biomonitor, air pollution, chlor-alkali.

\section{RESUMO}

\section{O biomonitor Tillandsia usneoides pode ser utilizado para estimar níveis ocupacionais e ambientais de mercúrio no ar?}

A barba-de-velho, bromélia epífita Tillandsia usneoides (Spanish moss na língua inglesa), tem sido usada como biomonitor para avaliar a presença de poluentes no ar. No presente artigo, concentrações de Hg total foram determinadas em bromélias expostas em diferentes áreas de uma fábrica de cloro-soda brasileira enquanto em laboratório foi construída uma curva de calibração em condições controladas visando estimar as concentrações de Hg na atmosfera. As determinações de Hg foram feitas por espectrofotometria de absorção atômica. No laboratório, a bromélia apresentou retenção linear $(\mathrm{r}=0,99 ; \mathrm{p}<0,05)$ quando exposta a diferentes concentrações durante 15 dias (condições controladas). A bromélia Tillandsia usneoides permitiu a monitoração contínua e simultânea de diversos espaços no interior da fábrica, identificando áreas mais críticas onde os trabalhadores podem estar mais intensamente expostos. A biomonitoração com bomélias não parece ser uma estratégia confiável para estimar as concentrações de $\mathrm{Hg}$ no ar com precisão analítica. Porém, esta ferramenta se mostra útil como um método para identificar áreas críticas em programas de prevenção de riscos ambientais e de saúde ocupacional.

Palavras-chave: mercúrio, Tillandsia usneoides, biomonitor, poluição do ar, cloro-soda.

*Corresponding author: Márlon de Freitas Fonseca, e-mail: marlon@biof.ufrj.br. 


\section{INTRODUCTION}

One of the most concerning sources of mercury $(\mathrm{Hg})$ contamination in urban areas are chlor-alkali plants where elemental mercury $\left(\mathrm{Hg}^{0}\right)$ is used as a catalyst in the electrolysis cells. In these industries, there is a high occupational risk to workers who are exposed to high levels of the contaminant, especially when electrolysis cells are opened (ATSDR, 1999; IPCS, 1976). The World Health Organization (WHO) has established the threshold limits for long-term occupational exposure to inorganic mercury compounds in air as $50 \mu \mathrm{g} \mathrm{m}^{-3}$ (WHO, 1980). The threshold limits for long and short-term exposure to metallic mercury $\left(\mathrm{Hg}^{0}\right)$, respectively 25 and 500 $\mu \mathrm{g} \mathrm{m}^{-3}$, might be important if the source is clearly metallic mercury, as in chlor-alkali plants (IPCS, 1991).

A continuous assessment of atmospheric $\mathrm{Hg}$ concentration in an industry can be used to determine occupational risk and provide more efficient industrial hygiene control and safety programs. The gas-snifters, usually used to estimate immediate $\mathrm{Hg}$ concentration in the air, exhibit some drawbacks: they are expensive; they do not integrate long periods of time; and they don't allow multiple simultaneous measurements, which are essential to consider peaks and values in unstable and nonuniform sources (Perry \& Young, 1997).

Spanish moss (Tillandsia usneoides) is an epiphyte bromeliad (without roots) with CAM (Crassulacean Acid Metabolism) type metabolism and stomas that open predominantly at night, avoiding water loss, and resisting large periods of exposure to the sun (Haslam et al., 2003). Moreover, it exhibits branched morphology and small scaly leaves that greatly increases deposition surface (Benzing \& Renfrow, 1980; Benzing, 1990; Husk et al., 2004). Amado Filho et al. (2002) demonstrated that most $\mathrm{Hg}$ accumulation is partly associated with atmospheric particles deposited upon the plant surface with scale, stem and leaf surfaces exhibiting higher absorption rates. For these reasons it has been used in tropical environments (in detriment of mosses and lichens) for monitoring atmospheric $\mathrm{Hg}$ as well as other pollutants (Calasans \& Malm, 1994; 1997a; Malm et al., 1998; Figueiredo et al., 2001, 2004; Cortés, 2004).

Our first objective in the present study was to make a calibration curve to estimate the atmospheric $\mathrm{Hg}$ amount exposing the biomonitor Tillandsia usneoides to different $\mathrm{Hg}^{0}$ concentrations in controlled conditions. We aimed also to evaluate $\mathrm{Hg}$ vapor exposure in a Brazilian chlor-alkali plant using this bromeliad placed in different zones of the factory in order to identify critical areas inside the industrial services and, if possible, to estimate atmospheric $\mathrm{Hg}$ concentrations in different sites. Furthermore, we also evaluated the analytical performance of the groups during an inter-comparison exercise between our laboratory and that of the industry. Moreover, the main goal was to gather both university and industry resources with the purpose of improving the quality of life and environmental preservation through the development of new environmental and occupational monitoring over and above worker education strategies.

\section{MATERIAL AND METHODS}

\section{The industry area and the biomonitor}

The surveys were conducted in October/November 1998 (first survey) and replicated in January/February 1999 (second survey), when there were higher temperatures. The plant was located in Rio de Janeiro city (Brazil) and was still using $\mathrm{Hg}^{0}$ in its process at that time. The industrial area was sub-divided into 4 zones for monitoring purposes:

1. One support building with offices, laboratories and warehouses - where there were neither electrolysis cells nor $\mathrm{Hg}^{0}$ sources such as machines, pumps, storage places, residual filth, etc. Hypothetically, these should be clean areas.

2. Two main independent buildings (electrolysis units: pavilions I and II) - where the electrolysis cells operated and it was known that high release of $\mathrm{Hg}^{0}$ occured (dirty areas). The pavilions had two floors and their electrolysis cells were placed on the second one. Each pavilion had an independent production line and its own operation room (I and II, respectively), where workers monitored the process. Hypothetically, these operation rooms should be clean areas. The pavilions also had other closed environments such as locker rooms and restrooms where workers stayed temporarily. Chronologically, pavilion I was constructed after the pavilion II and, because of this, its project was more modern and had relative advantages such as better air circulation.

3. The external area (outdoor environment) - areas around the buildings which are more susceptible to wind and dust. One special outdoor spot was chosen because the presence of opened machines for maintenance activities such as the pumps of $\mathrm{Hg}$.

Tillandsia usneoides samples were provided by the Rio de Janeiro Botanical Garden, an area comparatively considered free from significant anthropogenic $\mathrm{Hg}$ input. Samples previously analyzed to estimate the background $\mathrm{Hg}$ values were below the detection limit. About $5 \mathrm{~g}$ of Tillandsia usneoides were accommodated in each plastic basket for exposure. One hundred and ninety plastic baskets with the bromeliads were distributed in four monitoring zones. In each monitored location, 2 plastic baskets (side by side) were placed about $2 \mathrm{~m}$ high from the floor; one was retrieved after 15 days and the other remained for a total period of 45 days exposure. These places were chosen considering the probability of $\mathrm{Hg}$ emissions as well as being places where workers remained for more time. Furthermore, some outdoor areas were surveyed to confirm if they really could be considered free (clean enough) for longterm permanence. The engineer and the physician of the plant were present and helped our team with this step. 
During the second survey, 10 sites were also selected for a more accurate investigation because it had been verified long-term permanence of workers as well as some points had appeared to be quite different, specially relating to environmental influences such as wind and dust occurrence (Table 1). In this approach, the lack of more protection against undesirable handling or dirt, and the necessity of multiple surveys were also tested. The evaluation of these sites was carried out in 15 days. In these 10 different environmental conditions, 3 baskets were put side by side so as to test if the systems are reproducible at the same site. Preliminary data (first survey in October/November 1998) and previous studies from our group have concluded that 15 days (compared to 45 days) is a reasonable time to identify the main sites (higher or lower $\mathrm{Hg}$ levels) through bromeliad $\mathrm{Hg}$ retention in occupational and environmental evaluations (Malm et al., 1998; Bastos et al., 2004).

In addition, during an analytical inter-calibration exercise between our laboratory and the industry (our laboratory was the reference), a total of 158 first-morning urine samples were randomly collected from workers in different departments of the industry. In our laboratory, urine digestion was performed according to Bastos et al. (1998), and bromeliads according to Calasans \& Malm (1997b). The Hg determinations were obtained by cold vapor atomic absorption spectrometry. Urine samples were analyzed in FIMS-400/AS-90 Perkin-Elmer and bromeliad extracts in Varian AA/1475-VGA/76. Detection limit for this method was $1.5 \mu \mathrm{g} \mathrm{L}^{-1}$ and $0.06 \mu \mathrm{g} \mathrm{g}^{-1}$ both FIMS and VGA systems, respectively. All the samples were analyzed in triplicate, including blank reagents. Certified reference sample (IAEA-140/TM) was analyzed for quality control and retrieval percentages were above $79 \%$.

In the plant laboratory, the analytical procedure was performed by Instituto Nacional de Seguridad e Higiene en el Trabajo de Ministério de Trabajo y Seguridad Social (Spain). The industry was participating in the Spanish quality control program (Programa de Intercomparação de Control de Calidad - PICC). The Hg determinations in urine samples were obtained by cold vapor atomic absorption spectrometry in a Colemam - Perkin Elmer spectrometer. This inter-comparison exercise was a method to certify analysis, and also to stimulate future studies between the two groups. Urine samples were chosen as the standard matrix because the industry did not perform bromeliad analysis as routine.

\section{Bromeliad validation in controlled conditions}

Three identical plastic baskets with bromeliads were simultaneously exposed in an exposure chamber (hermetic glass vial with $\cong 6 \mathrm{~L}$ ) during 15 days to different controlled atmospheres with known $\mathrm{Hg}$ concentrations. The experience was repeated five times in our laboratory, and the obtained $\mathrm{Hg}$ concentrations were $0 ; 3 ; 36 ; 241$; and $332 \mu \mathrm{g} \mathrm{m}^{-3}$. The experimental model (controlled exposure chamber) suggested some parameters that interfere in the desirable constant release of a $\mathrm{Hg}$ source, such as vapor generation of a $\mathrm{Hg}$ drop. Empirically, the influence of temperature on bromeliad adsorption as well as the presence or absence of dust (verified with and without cotton filter) was controlled to obtain constant known atmospheres. This system should be built with common available laboratory devices (glass, connections, air pumps, reagents, etc.) and validated by scientific methods because the obvious low cost and trustworthy exigencies.

A Hg vapor generator (a glass $\mathrm{T}$ cylinder containing a metallic mercury drop in the base and an air filter in the entrance) was coupled to the chamber entrance. A bubble trap (bubbler), containing a $\mathrm{KMnO}_{4} 0.1 \mathrm{~N}+\mathrm{H}_{2} \mathrm{SO}_{4} 10 \%-1: 1$ solution, oxidizes and solubilizes all $\mathrm{Hg}$ from the outgoing air. This solution prevents loss by volatilization (Kudsk, 1964; Usepa, 1983; Malm et al., 1990). A constant air flux (1 L $\mathrm{min}^{-1}$ ) is driven by a vacuum pump passed through the T head carrying $\mathrm{Hg}$ to the chamber by way of the Venturi effect. A magnetic anchor in the bottom of the chamber ensured equal dispersion of $\mathrm{Hg}$. The different concentrations inside the chamber were achieved empirically by changing the $\mathrm{T}$ generator - different cylinder tube diameters and different surface area (mass) of the $\mathrm{Hg}^{0}$ drop. The $\mathrm{Hg}$ source was immersed in an ethylene glycol solution with a thermostat to help keep the temperature constant. A cotton filter was placed in the entry of the system to avoid dust. We have previously noticed that this is an important source of variation in atmospheric $\mathrm{Hg}$ concentration inside the chamber. This bubbler system is validated for determining total $\mathrm{Hg}$ concentration in the air accurately (Kudsk, 1964; Usepa, 1983; Malm et al., 1990) (Figure 1). The average Hg air concentration in the chamber $([\mathrm{Hg}])$ was achieved using this formula, where $f$ was the air flux; $m$ was the $\mathrm{Hg}$ mass retained in the bubble trap; and $t$ was the total duration of the air sampling:

$[\mathrm{Hg}]\left(\mu \mathrm{g} \mathrm{m}{ }^{-3}\right)=m(\mu \mathrm{g}) . t(\min ) / f\left(\mathrm{~L} \mathrm{~min}^{-1}\right) \cdot 10^{-3}$

\section{RESULTS AND DISCUSSION}

\section{Hg retention in the industrial area}

Total Hg concentrations in Tillandsia usneoides from different points of the industrial area are shown in Figures 2 and 3. As expected, total $\mathrm{Hg}$ concentrations were relatively higher than background values, but markedly variable inside the electrolysis pavilions. Lower $\mathrm{Hg}$ values were detected at the main building and in the external area around the pavilions, as expected. The exposed bromeliad in external areas showed more regular enrichment from 15 to 45 days of exposure when compared to dirty indoor environments (pavilions I and II), which showed important outliers. The more homogeneous atmosphere outside the pavilions associated to lower $\mathrm{Hg}$ levels 
as well as the lower possibility of gross contamination from a dirtier particulate can probably explain this behavior. It is important to have in mind that even a very small drop of $\mathrm{Hg}$ on the bromeliad surface can generate an outlier. The pumps, which were used to pump $\mathrm{Hg}$ to the electrolysis cells, had their maintenance done in an outdoor environment to diminish occupational exposure to residual $\mathrm{Hg}$. Curiously, although placed in an open area, the maintenance pump site caused an increased $\mathrm{Hg}$ adsorption in the exposed bromeliad. This fact was communicated to the Occupational Health Program responsible in order to prevent long permanence with probable excessive exposure in this site (Table 1). These bromeliads exposed outdoors showed higher levels when exposed during the hotter season (Jan/Feb). It is probable that this occurred as a consequence of particulate contribution - because of stronger and more frequent winds during this season - associated to high temperatures (up to $40^{\circ} \mathrm{C}$ ). Although the pavilions had few walls, this seasonal adsorption difference was not observed there probably due to the lower effect of wind.

The higher $\mathrm{Hg}$ values in bromeliads exposed for 15 days from pavilion I were observed on the ground floor under the electrolysis cells $\left(655 \mu \mathrm{g} \mathrm{g}^{-1}\right)$ and, about $10 \mathrm{~m}$ above them, on the tower pavement beside the $\mathrm{NaOH}$ reservoir $(734 \mu \mathrm{g}$ $\left.\mathrm{g}^{-1}\right)$, probably the leading contaminated area. On the other hand, the lower values (33.3 and $\left.73.6 \mu \mathrm{g} \mathrm{g}^{-1}\right)$ were obtained inside the operation office I. In the remaining sampling baskets, distributed around and above electrolysis cells, the median $\mathrm{Hg}$ concentration was $177 \mu \mathrm{g} \mathrm{g}^{-1}$. At pavilion II (15 days exposure), the lowest $\mathrm{Hg}$ concentration was found in the sampling baskets inside the restroom $\left(13.7 \mu \mathrm{g} \mathrm{g}^{-1}\right)$. In the operation office II the concentration was also low $(48.9 \mu \mathrm{g}$ $\left.\mathrm{g}^{-1}\right)$. The median $\mathrm{Hg}$ concentration around the electrolysis cells was $258 \mu \mathrm{g} \mathrm{g}^{-1}$ with the highest value being $552 \mu \mathrm{g} \mathrm{g}^{-1}$ (Figure 3).

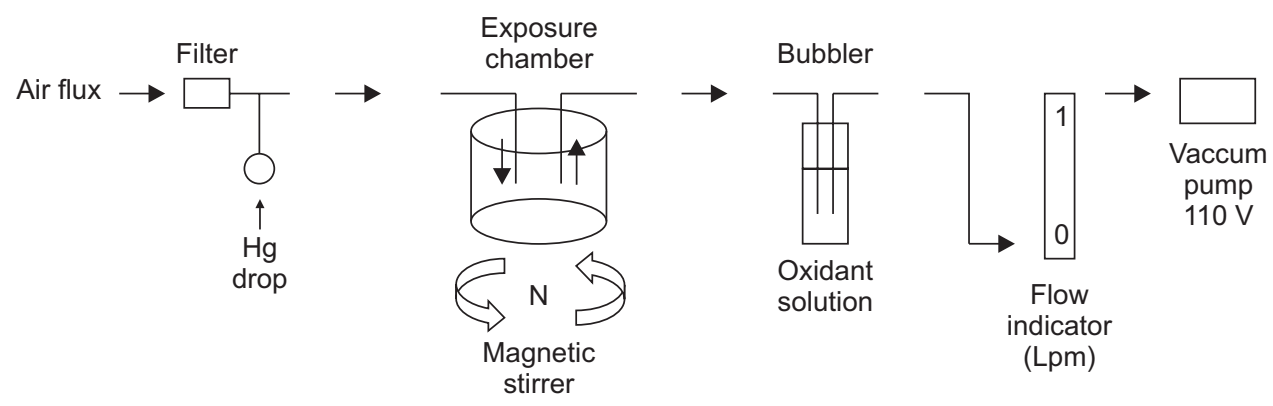

Figure 1 - Experimental model for exposing Tillandsia usneoides to known $\mathrm{Hg}^{0}$ air concentrations. Inside the chamber, 3 bromeliad samples were concomitantly exposed to each atmosphere.

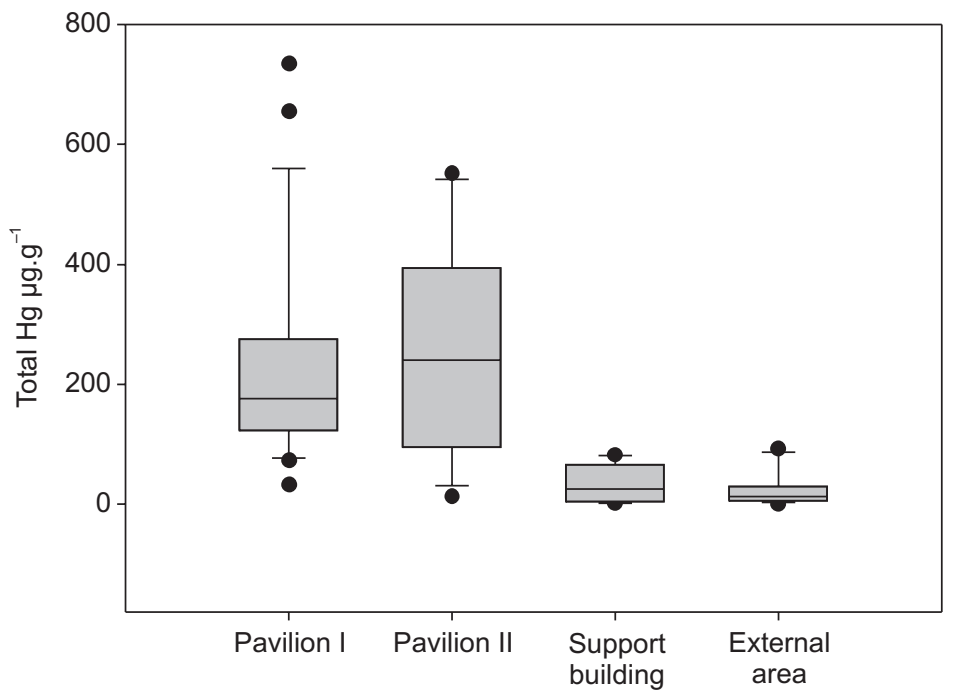

Figure 2 - Box-plot graph of total Hg concentrations in 15 days exposed Tillandsia usneoides in different areas of the chlor-alkali plant. Boxes are 25 and 75 percentiles with median value. Bars represent minimum and maximum limits. Dots are extreme values. 

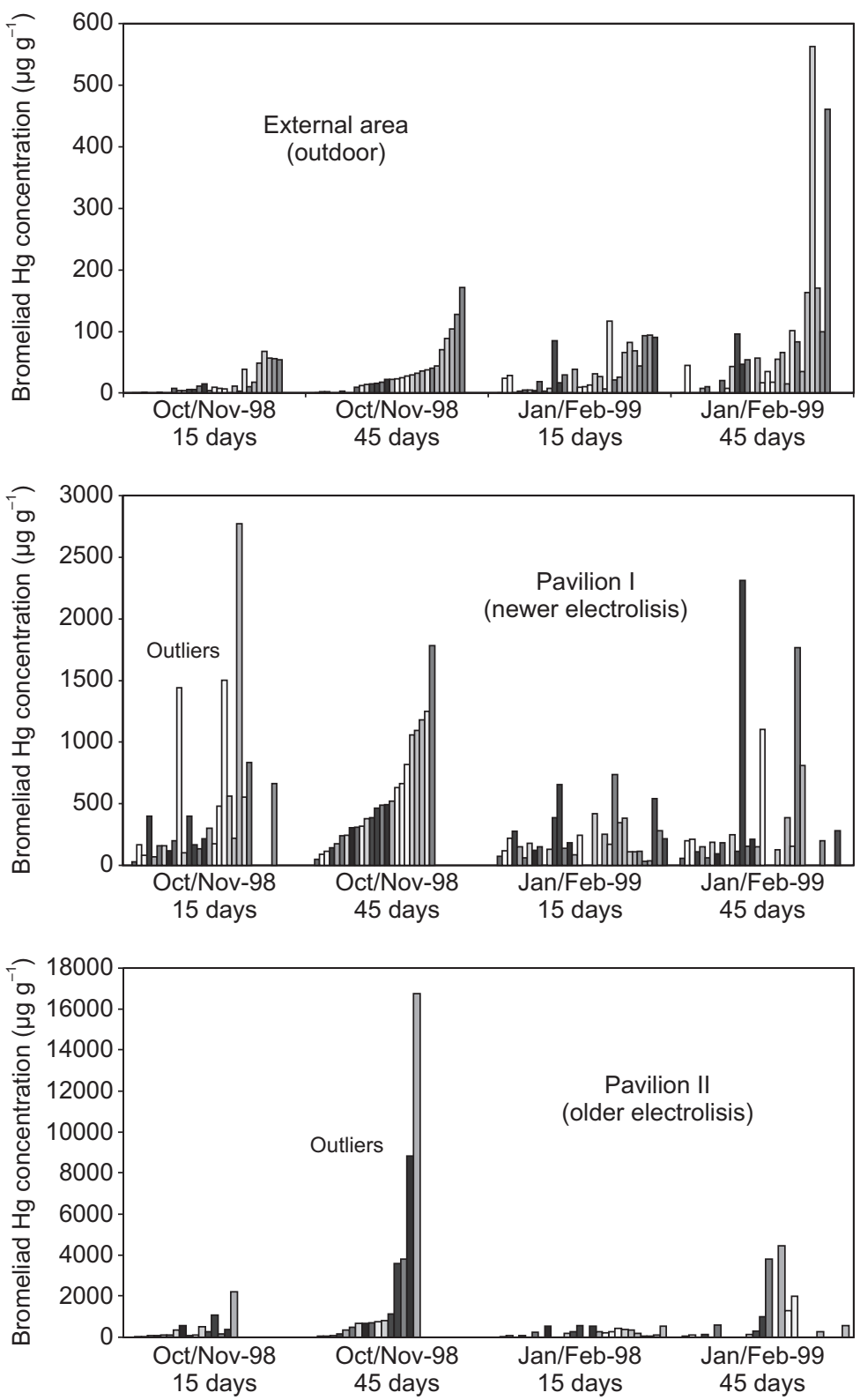

Figure $3-\mathrm{Hg}$ concentration in bromeliads exposed in different areas of the factory for 15 and 45 days. First survey $=$ October and November 1998; second survey = January and February 1999; for comparison purposes, the longer exposure time in the second survey was arbitrarily considered as standard.

Fortunately, $\mathrm{Hg}$ concentrations in bromeliads of operation offices where workers spend more time were lower than around the electrolysis cells, where laborers went just for short visits. One basket placed on the first floor showed a high value after exposed for 45 days $\left(16800 \mu \mathrm{g} \mathrm{g}^{-1}\right)$. In this area we could perceive small drops of $\mathrm{Hg}$ around the plastic baskets and over their acrylic protection. Probably, they came from dirt on the workers feet over the grated ramp, an undesireable event. Of course, these are not good sites to survey. This fact was not observed in the newer building, pavilion I. The support building comprises all the closed environments monitored outside the industrial pavilions. The median value for bromeliads exposed in different rooms was $24.9 \mu \mathrm{g} \mathrm{g}^{-1}$. The lowest $\mathrm{Hg}$ values were obtained in bromeliads placed inside the medical and engineering offices, and at the central laboratory $(1.84 ; 2.80$ and $4.74 \mu \mathrm{g} \mathrm{g}^{-1}$, respectively). Higher concentrations were found in samples of two warehouses and the incinerator room (respectively $65.5 ; 68.6$ and $82.6 \mu \mathrm{g} \mathrm{g}^{-1}$ ), as expected. In external open areas around the pavilions, bromeliads exhibited low concentrations (median $13.1 \mu \mathrm{g} \mathrm{g}^{-1}$ ), with the exception of the basket exposed at the site where the Hg pumps are opened for maintenance $\left(92.7 \mu \mathrm{g} \mathrm{g}^{-1}\right)$. 
Table 1 shows the Hg concentration in the bromeliads exposed in triplicate for 15 days at the 10 selected occupational sites. The values exhibited good reproducibility with a coefficient of variation (CV) usually under $20 \%$. In the medical office, the highest CV (92.9\%) was observed simultaneously with the lowest mean values. We consider that in less contaminated environments, where bromeliads exhibited $\mathrm{Hg}$ concentrations closer to background values, this is acceptable because the risk is probably quite low.

Besides, basket handling may have been the main responsible for the high variability among the triplicates from some other sites, specially in the dirtiest ones. The variability observed in samples from some electrolysis cells in pavilions I and II could represent the non-uniformity of local atmospheric contamination, including dust. Since the 3 baskets were put together in each sampling location, it is also possible that one could have worked as a protection shield to the other, changing the retention rate in each of the three baskets.

$\mathrm{Hg}$ concentrations in the bromeliads exposed in the industrial facilities were also much higher than those found in the controlled experiment in the exposure chamber and this fact corroborates the probable effect of dirt. Despite the low accuracy and analytical cost (about US $\$ 20,00$ per sample analyzed in triplicate), it is important to consider that this approach can show some advantages. Considering these coefficients of variation, we think it is probable that the use of just one basket in each sampling location in a continuous monitoring program (for example, 15 days a month along one semester) may be more strategic. This allows a plant to observe an eventual tendency in some areas to become more or less insalubrious. Moreover, the laboratory analysis would become less expansive and the main advantages of the system (monitoring several sites simultaneously) would be benefited.

\section{Human risk evaluation during the analytical inter-comparison exercise}

When workers are exposed to $\mathrm{Hg}$ vapor in the occupational environment, the best compartment to exposure assessment is the amount of $\mathrm{Hg}$ in urine samples. The threshold limit established by WHO to $\mathrm{Hg}$ in urine is $50 \mu \mathrm{g} \mathrm{g}^{-1}$ of creatinine (IPCS, 1991; Barregard, 1993; ATSDR, 1999). Although creatinine is used to partially reduce the variability due to dilution of spot urine samples, several studies have considered unnecessary to use this correction (Soleo et al., 1990; Malm et al., 1995).

The chlor-alkali plant surveyed in this study had a continuous program to minimize occupational risk. As the normal range of creatinine in urine averages about $1 \mathrm{~g} \mathrm{~L}^{-1}$ in healthy individuals (0.6-1.8), a preliminary approach were conduced by the Occupational Health and Safety Program of this plant without the creatinine correction as routine to minimize the cost of repeated analysis. After this screening, workers who presented urine $\mathrm{Hg}$ levels above $30 \mathrm{~g} \mathrm{~L}^{-1}$ underwent more accurate laboratory examination while an individual occupational evaluation was made by an industry physician. Thus, both urine and air measurements were used by Occupational Medicine and Safety Engineering so as to promote safer work conditions in this plant.

Concentration in the workers' urine was highly variable (median 21.5; $\max 616$; $\min 2.7 \mu \mathrm{g} \mathrm{L}^{-1}$ ) representing the heterogeneity of the 158 samples. Despite the low median concentration value, about $25 \%$ of the samples were above $50 \mu \mathrm{g} \mathrm{L}^{-1}$ and about $7.6 \%$ were above the $100 \mu \mathrm{g} \mathrm{L}^{-1}$. The probability to develop classical neurological symptoms to mercury intoxication is undoubtedly higher at these levels (IPCS, 1991; ATSDR, 1999), and a continuous occupational evaluation is imperative as well.

Table 1 - Reproducibility of 3 Tillandsia usneoides sampling systems ( 3 plastic baskets) simultaneously placed in 10 selected sites of factory (SD = standard deviation of the averaged 3 baskets; $\mathrm{CV}$ = coefficient of variation; *closed environments; $\mathrm{Hg}$ concentration in $\mu \mathrm{g} \mathrm{g}^{-1}$ ).

\begin{tabular}{ccccc}
\hline Local & Description & Mean & SD & CV \\
\hline Main building & Medical office* & 1.84 & 1.70 & $92.9 \%$ \\
Main building & Central laboratory* & 4.74 & 0.73 & $15.3 \%$ \\
Electrolysis I & Operation room* & 33.3 & 3.9 & $11.8 \%$ \\
Electrolysis II & Operation room* & 48.9 & 3.7 & $7.5 \%$ \\
External area & Hg pump maintenance & 92.7 & 2.2 & $2.3 \%$ \\
Electrolysis I & Main corridor & 110.0 & 2.7 & $2.4 \%$ \\
Electrolysis I & Above the cells & 247.2 & 47.1 & $19.1 \%$ \\
Electrolysis II & Above the cells & 343 & 183 & $53.3 \%$ \\
Electrolysis II & Above the cells & 351 & 81 & $23.2 \%$ \\
Electrolysis I & Above the cells & 363 & 27 & $7.4 \%$ \\
\hline
\end{tabular}


After the analytical inter-comparison exercise, the performance of the laboratories was very similar and the regression analysis shown the equation: $y=0.98 x+2.82(\mathrm{r}=$ $0.94 ; \mathrm{n}=117$ ), where $y$ and $x$ are, respectively, industry and LREPF $\mathrm{Hg}$ concentration results in $\mu \mathrm{g} \mathrm{L}^{-1} ; \mathrm{n}=$ number of samples evaluated after an analytical interchange exercise between the both technical groups and optimizations in industry routine. We think that inter-calibration exercises may stimulate both new occupational studies with security and validation of continuous bromeliad use by industries themselves in the future, while $\mathrm{Hg}^{0}$ takes place in the process.

In relation to human health, our purpose was not to evaluate individual exposure but the factory environment. Besides, employees did not stay in the same place during their work day and they always passed through different areas. Thus, we can not compare individual exposure parameters (such as urine $\mathrm{Hg}$ amount) to exposed bromeliads. However, the overexposed workers were evaluated by the occupational physician of the industry through a continuous internal Occupational Health Program. Thus, samples that shown high values were justly identified and the finding were communicated to the Occupational and Environmental Medical Department of the industry.

\section{Hg retention in the exposure chamber}

Tillandsia usneoides exhibited linear $\mathrm{Hg}$ retention $(\mathrm{r}=$ $0.99 ; \mathrm{p}<0.05$ ) over a determined range of concentrations (up to $332 \mu \mathrm{g} \mathrm{m}^{-3}$ ) when exposed to a controlled atmosphere in the laboratory for 15 days (Figure 4). This result demonstrates that, when atmosphere conditions are stable and the air is dust free, this bromeliad displays linear accumulation along time and the accumulation can be predicted by the equation $y=$ $0.008 x+0.035(\mathrm{r}=0.99 ; \mathrm{p}<0.05)$, where $y$ is bromeliad $\mathrm{Hg}$ concentration in $\mu \mathrm{g} \mathrm{g}^{-1}$ and $x$ is $\mathrm{Hg}$ concentration the air in $\mu \mathrm{g} \mathrm{m}^{-3}$.
This linearity allows a better understanding of retention rate data, suggesting that microclimate conditions in industrial services (even gross contamination) may have been responsible for observed high coefficient of variation in some basket triplicates (Table 1). However, we cannot guarantee that the concentration retained in the bromeliads represents the exposure to a certain average concentration over a defined period. In a recent publication (Bastos et al., 2004), we observed that Spanish moss exposed in gold trade shops in the Amazon had much higher concentrations than ones exposed in the laboratory to similar atmosphere values. Actually, the $\mathrm{Hg}$ atmospheric concentration was not estimated in the Amazon, but directly measured with the same validated reference bubblers system (Kudsk, 1964; Usepa, 1983; Malm et al., 1990). This system is able to collect all the $\mathrm{Hg}$ from the air, without loss, throughout a determined period of time. In that article (Bastos et al., 2004), we suggested that the high concentration of suspended particles in the air, associated with high humidity, could favor the adsorption of $\mathrm{Hg}$ to particles and its retention to bromeliad's scales. Therefore, our new results in a chlor-alkali plant from Rio de Janeiro seems to confirm that this bromeliad can retain $\mathrm{Hg}$ more efficiently in outdoor environments than in indoor ones, even with quite similar total $\mathrm{Hg}$ concentrations in the atmosphere.

The lack of dust and the drier atmosphere in a laboratory environment can explain this difference. Besides, the relative low pressure created inside the exposure chamber (vacuum pump that drives the air flux) might make the $\mathrm{Hg}$ vapor retention more difficult. Consequently, our results shows an important limitation to use this bromeliad as a predictor of air $\mathrm{Hg}$ concentrations, unless a new calibration takes into account these outdoor environment components. We believe that if we had used the curve (Figure 4) to estimate the air Hg concentration in industry environment, the values would have been even more than 400 times higher than that measured with the bubbler systems, as found in Amazon (Bastos et al., 2004).

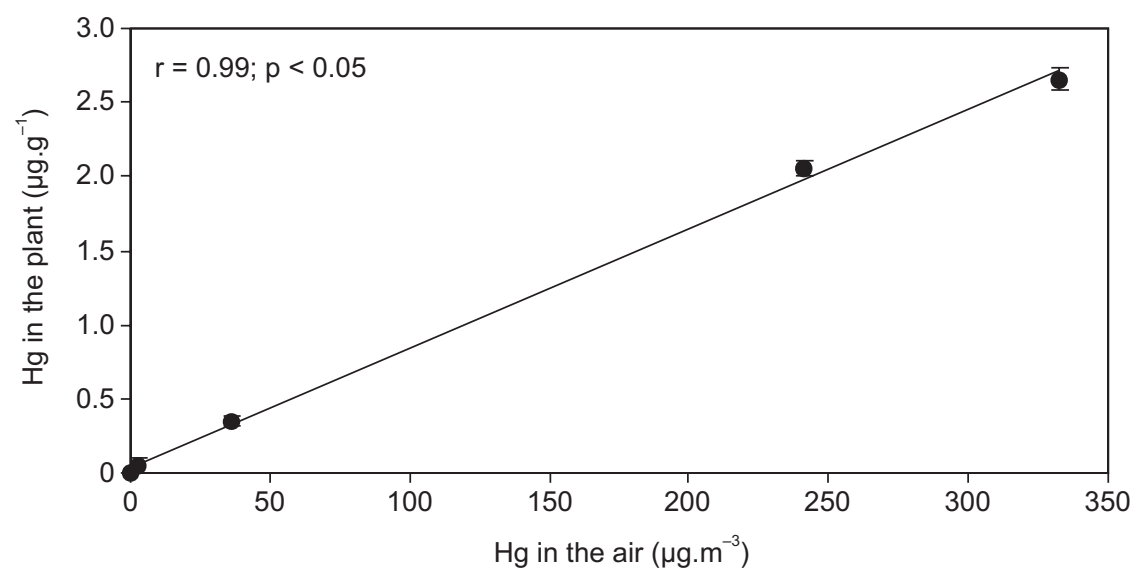

Figure 4 - Calibration curve for Hg concentrations in the air and in the exposed Tillandsia usneoides. $\mathrm{r}=$ Pearson's correlation coefficient between mean $\mathrm{Hg}$ air concentrations $\left(0 ; 3 ; 36 ; 241 ; 332 \mu \mathrm{g} \mathrm{m}^{-3}\right)$ and their 3 concomitant exposed bromeliads (3 baskets). Error bars stands for standard deviation of triplicates $(y=0.008 x+0.035)$. 
After this study, the industry have stopped the use of $\mathrm{Hg}^{0}$ and have implanted the more ecologically sound process in the chlor-alkali plant, the membrane system.

\section{CONCLUSION}

The biomonitor Tillandsia usneoides presented a linear correspondence with $\mathrm{Hg}$ concentrations in the atmosphere as demonstrated by the calibration curve built in the laboratory, under controlled conditions. However, despite the high correlation between $\mathrm{Hg}$ concentrations in exposed bromeliads and in the air, it should not be used to accurately estimate $\mathrm{Hg}$ air concentration in non-controlled conditions. Environmental factors such as temperature, humidity and suspended particles might influence the retention by the bromeliads, overestimating atmospheric $\mathrm{Hg}$ concentrations. Moreover, proper handling of the contaminant in an industrial process that employs high amounts of $\mathrm{Hg}$ is fundamental in creating a clean environment where retention in bromeliads is the result of the displacement of particles carrying $\mathrm{Hg}$, and not contamination due to misuse of it. However, the use of sentinel species and biomonitors, such as Spanish moss (Tillandsia usneoides) permit the simultaneous and continuous monitoring of industrial areas. They also help to identify areas with higher exposure rates, and can aid occupational physicians and safety engineers in elaborating better safety procedures. Although the ideal condition is the abolishment of the utilization of $\mathrm{Hg}$ in chloralkali plants (a strong worldwide tendency), occupational assessment must be maintained after this to be sure that there is no significant persistence of this pollutant where people work. Therefore, considering that bromeliad validation under controlled conditions in laboratory is not possible, local calibration should be tested in order to integrate and, possibly, more accurately estimate $\mathrm{Hg}$ concentration in the air along a determined period of time. To regulate this biomonitor, a validated reference system able to collect outdoor air samples during the same period in which the bromeliad will be exposed (including small breathable particles) will be necessary. Occupational health education programs must be maintained for factory workers considering $\mathrm{Hg}$ exposure and hygiene measures. The use of this biomonitor can be a useful method to identify and to assess critical sites in continuous occupational and environmental control risk programs, or even in helping educational activities. Since this study was completed, the industry stopped the use of $\mathrm{Hg}$ and implanted the more ecologically sound process of the membrane system for chloralkali plants.

Acknowledgements - This work was supported by Pan-americana s/a grant number: 0003/99 and CNPq; Dr. Torres and Dr. Rebelo are Selikoff Fellows at the Mount Sinai School of Medicine and Queens College in New York and are supported in part by grant $1 \mathrm{~d} 43$ tw00640 from the Fogarty International Center of the National Institute of Health (NIH). The authors also are indebted to the workers of Pan-americana S/A (Honório Gurgel plant in Rio de Janeiro) for full cooperation with this study - this company carries on a continuous program of $\mathrm{Hg}$ monitoring in the air and in employees' urine. This manuscript is dedicated to Prof. Dr. Gilberto Amado Filho (from Botanic Garden of Rio de Janeiro), a special friend and reviewer.

\section{REFERENCES}

AMADO FILHO, G. M., ANDRADE, L. R., FARINA, M. \& MALM, O., 2002, Hg localization in Tillandsia usneoides L. (Bromeliaceae) an atmospheric biomonitor. Atmos Environ., 36: 881-887.

ATSDR (Agency for Toxic Substances and Disease Registry), 1999, Toxicological Profile for Mercury (Update). U.S. Department of Health \& Human Services, Public Health, Service.

BARREGARD, L., 1993, Biological monitoring of exposure to mercury vapor. Scand. J. Work Environ. Health 1: 45-49.

BASTOS, W. R., FONSECA, M. F., PINTO, F. N., REBELO, M. F., SANTOS, S. S., SILVEIRA, E. G., TORRES, J. P. M., MALM, O. \& PFEIFFER, W. C., 2004, Mercury persistence in indoor environments in the Amazon Region - Brazil. Environ. Res., 96: 235-238.

BASTOS, W. R., MALM, O., PFEIFFER, W. C. \& CLEARY, D., 1998, Establishment and analytical quality control of laboratories for $\mathrm{Hg}$ determination in biological and geological samples in the Amazon-Brazil. Cien. Cult., 50: 255-260.

BENZING, D. H. \& RENFROW, A., 1980, The nutritional dynamics of Tillandsia circinnata in southern Florida and origin of the "air plant" strategy. Bot. Gaz., 141: 162-165.

BENZING, D. H., 1990, Vascular epiphytes. Cambridge Tropical Biology Series. Cambridge.

CALASANS, C. F. \& MALM, O., 1994, Using Tillandsia usneoides to monitor air pollution by mercury. Rev. Soc. Bras. Bromélias, 1: 7-10.

CALASANS, C. F. \& MALM, O., 1997a, Elemental mercury contamination survey in a chlor-alkali plant by the use of transplanted Spanish moss, Tillandsia usneoides (L.), Sci. Total Environ., 208: 165-177.

CALASANS, C. F. \& MALM, O., 1997b, Plant sample digestion for mercury analysis by atomic absorption spectrophotometry with a cold vapor generation accessory (AAS-VGA). Cien. Cult., 49: 213-216.

CORTÉS E. Investigation of air pollution in Chile using biomonitors, 2004 J. Radioanal Nuc. Chem., 262(1): 269-276.

FIGUEIREDO, A. M. G.; ALCALÁ, A. L.; TICIANELLI, R. B.; DOMINGOS, M. \& SAIKI, M., 2004, The use of Tillandsia usneoides L. as biomonitor of air pollution in São Paulo, Brazil. J. Radioanal. Nuc. Chem., 259: $59-63$.

FIGUEIREDO, A. M. G., SAIKI, M., TICIANELLI, R. B., DOMINGOS, M., ALVES, E. S. \& MARKERT, B., 2001, Determinatoin of trace elements in Tillandsia usneoides by neutron activation analysis for environmental biomonitoring. J. Radioanal Nuc. Chem., 249: 391-395.

HASLAM, R., BORLAND, A., MAXWELL, K. \& GRIFFITHS, H., 2003, Physiological responses of the CAM epiphyte Tillandsia usneoides L. (Bromeliaceae) to variations in light and water supply. J. Plant Physiol., 160: 627-634.

HUSK, G. J., WEISHAMPEL, J. F. \& SCHLESINGER, W. H., 2004, Mineral dynamics in Spanish moss, Tillandsia usneoides L. (Bromeliaceae), from Central Florida, USA. Sci. Total Environ., 321: 165-172.

IPCS [International Program on Chemical Safety], 1976, Mercury (Environmental Health Criteria 1). World Health Organization, Geneva.

IPCS [International Program on Chemical Safety], 1991, Inorganic mercury (Environmental Health Criteria 118). World Health Organization, Geneva.

KUDSK, F. N., 1964, Chemical determination of Hg in air: An improved dithizone method for determination of mercury and mercury compounds. Scand. J. Clin. Lab. Invest., 16: 1-15. 
MALM, O., PFEIFFER, W. C., SOUZA, C. M. M. \& REUTHER, R., 1990 Mercury pollution due to gold mining in the Madeira river basin, Brazil. Ambio, 19: 11-15.

MALM, O., CASTRO, M. B., BASTOS, W. R., BRANCHES, F. J. P., GUIMARÃES, J. R. D., ZUFFO, C. E. \& PFEIFFER, W. C., 1995, An assessment of $\mathrm{Hg}$ pollution in different gold mining areas, Amazon Brazil. Sci. Total Environ., 175: 127-140.

MALM, O., FONSECA, M. F., HISSNAUER, P. M., BASTOS, W. R. \& PINTO, F. N., 1998, Use of epiphyte plants as biomonitors to map atmospheric mercury in a gold trade center city, Amazon, Brazil. Sci Total Environ. 213: 57-64.
PERRY, R. \& YOUNG, R., 1977, Handbook of air pollution analysis. Chapman and Hall Ltd., Cambridge.

SOLEO, L., URBANO, M. L., PETRERA, V. \& AMBROSI, L., 1990, Effects of low exposure to inorganic mercury on psychological performance. Brit. J. Ind. Med., 47: 105-109.

USEPA [U.S. Environmental Protection Agency], 1983. Methods of chemical analysis of water and wastes. Report 1V EPA A 600/4-79-020. Ohio.

WHO [World Health Organization], 1980. Recommended health-based limits in occupational exposure to heavy metals. (WHO Technical Report Series No. 647). Geneva. 
